\title{
Superficial Spreading Adenocarcinoma
}

National Cancer Institute

\section{Source}

National Cancer Institute. Superficial Spreading Adenocarcinoma. NCI Thesaurus. Code C4125.

An adenocarcinoma which has spread within the mucosa without further invasion of the underlying tissues. 